Acta Poetica $33 \cdot 2$

JULIO-DICIEMBRE

$2012(167-180)$

\title{
Paradoxical Authorship: Tracing Authority in the Gorakhbān̄
}

\author{
Christine Marrewa Karwoski
}

¿Cómo podemos entender a un autor que pudo o no haber existido hace cientos de años, pero que resulta crucial para la comprensión de un texto? Se cree que el Gorakhbāṇ̄, un texto filosófico que contiene las enseñanzas del yogui Gorakh, fue compuesto en algún momento del siglo XVII. Entre otras cosas, el texto hace hincapié en la necesidad de un maestro o gurú para comprender el verdadero significado: "La palabra verdadera constituye un cálculo de oro. Quien carece de maestro es un impostor, el discípulo de un gurú permanece virtuoso. Quien deambula sin maestro cae en el vicio" (Barthwal, Gorakh-Bānī, 149). Sin embargo, el gurú al que se refiere este texto es el asceta indio semilegendario Guru Gorakhnāth, quien se cree que vivió cientos de años antes de la composición del texto. Esta problemática ocasiona dificultades específicas al tratar la cuestión de la autoría de este texto premoderno.

En este ensayo, mi argumento es que es necesario concebir a este guru como el autor del texto. Mientras que su existencia es fundamental para comprender la veracidad del texto, al mismo tiempo él resulta necesariamente inexistente. Recurriendo a las teorías de Roland Barthes y Michel Foucault, el objetivo es sugerir que la autoría del Gorakhbāṇī debe entenderse según su propio y paradójico rubro.

Palabras clave: literatura en hindi, India premoderna, teoría literaria, Nāth sampradāy, Sant Bhāșā

How do we understand an author who may or may not have existed hundreds of years ago, but is necessary to true comprehension of a text? The Gorakhbānin, the teachings of Gorakh, is a philosophical text believed to have been composed sometime in the seventeenth century. Amongst other things, it stressed the necessity of a teacher or guru to understand true meaning stating, "The word of truth is a golden calculation. He who is without a teacher is an impos- 
ter, the disciple of the teacher remains virtuous. He who is wandering without a guru falls into vice" (Bathwal, Gorakh-Bānī, 149). However, the guru that this text is attributed to is the semi-legendary Indian ascetic Guru Gorakhnāth who is believed to have lived hundreds of years previously, if at all. This problem creates specific difficulties when it comes to understanding the authorship of this pre-modern Indian text.

In this essay I argue that the guru that is discussed throughout this text needs to be equated with the author of the text. While his existence is imperative to the understanding of the truth of this text, he is also necessary nonexistent. Building upon the theories of Roland Barthes and Michele Foucault, the aim of this paper is to suggest than the authorship of the Gorakhbānin should be understood according to its own paradoxical rubric.

KEYwoRdS: Hindi literature, pre-modern India, literary theory, Nāth sampradāy, Sant Bhāṣā.

Fecha de entrega: 14 de diciembre de 2011

Fecha de aceptación: 16 de mayo de 2012 


\author{
Christine Marrewa Karwoski \\ Columbia University
}

\title{
Paradoxical Authorship: Tracing Authority in the Gorakhbāṇ̄
}

The written word as a means of communication is fundamentally problematic. While often writing is employed to convey and disseminate sets of ideas to a broader group of people - people to whom the author may not have immediate access, nor have intended to have communicated with - the disjuncture between the producer of the idea and the audience is inherently troublesome. The significance of the author's writings and the significance of the words which are received by the audience are necessarily divorced from one another through circumstances of time and place. This complex relationship which exists between the audience and the author has given rise to a series of theoretical questions concerning the ways in which the author should be understood. This dilemma of understanding authorship has prompted scholars to address this issue from a range of positions. Roland Barthes, more than a half of a century ago, approached this problem by declaring the author dead and began the process of burying authorial intent. In his seminal article "The Death of the Author," Barthes suggests that the author's intent is impossible to accurately establish and that the multiplicity of authorial meanings is focused not on the author but on the understanding of the reader (148). He considered it necessary for the author to metaphorically die in order for the modern reader's authority to be born in the world of literature. However, this proposition is not without dispute. Michel Foucault reminded audiences that narrative is also a sort of literary al- 
chemical stone, rendering the author immortal. The question that arises in the study of South Asia literature is can modern Western theories be applied to the study of pre-modern Indian authorship? I would like to suggest that this is indeed possible and helpful, particularly in the case of the seventeenth-century poetry of the semi-legendary Indian ascetic, Guru Gorakhnāth. The following essay will demonstrate how combining the theories of Barthes and Foucault help us understand the issue of authorship in the Gorakhbānn̄, and how its author Guru Gorakhnāth and his authority must be seen as paradoxically both immortal and dead.

\section{Authorship}

Since the early nineteenth century, conceptions of authorship in an Indian context began to take on markedly different significance. The influence of modernity, print culture, and the ever important establishment of copyright laws in South Asia stressed the significance of the textual author and authorial intent as not previously demonstrated. The author began to be considered as the originator and proprietor of the work in question, possessing it as if it were singularly his own creation (Rose, Authors and Owners, 2). While the influences of others' intellectual authorship were often conspicuously imprinted on any given piece of prose or poetry, modernity ensured that the composer who rearranged these ideas began to be celebrated in society as the "Author" of the work and that Author is seen as the inventor of the idea, the owner of the thoughts that are contained within the work and the artist who fashioned the text which is considered to be completely his own, both intellectually and financially.

Many scholars have suggested that this may not be the most successful manner for understanding texts, in a pre-modern South Asian context. Sheldon Pollock has shown that for centuries many Sanskrit texts excluded the names of the authors and the participants who took part in intellectual discourses ("New Intellectuals", 7). Other scholars such as John Stratton Hawley have stressed that the designation of author in Hindi literature is not necessarily used as a literal designation as such, as it is an affirmation of the author's authority ("Author and Authority", 
270). Christian Novetzke has suggested that the text (or performance) is the creative property of groups of individuals which make up a complex author ("Divining an Author: The Idea of Authorship in an Indian Religious Tradition", 238).

Building upon the claims articulated by Barthes and Foucault, I will suggest a different way in which we may be able to consider authorship in a pre-modern Indian context. Due to the gravity placed on the spiritual importance of the teacher within the Gorakhbāni and according to the text itself, Gorakhnāth himself must necessarily be regarded its author. As Gorkhanāth is the paradigmatic guru of the Nāth community, without his guidance his disciples would be unable to comprehend his esoteric message. However, the literary techniques and paradoxical language employed in the text force the listeners and readers of the Gorakhbāni to come to terms with the contradictions within it. The disciple's power to claim authority over the text's message is at times equal to that of Gorakhnāth, rendering the guru in the irrevocably paradoxical position of being both the text's immortal author and an empty authority. In short, I am proposing that Gorkhanāth's authorship should be understood according to the text's own paradoxical rubric. The author, like the text, is in a sense a secret.

\section{The Background}

To understand Gorakhnāth's authorship of the Gorakhbānī, it is first necessary to examine the history surrounding the guru and his literature. Little is historically known about Guru Gorakhnāth and no conclusive data survive concerning the ascetic's life, therefore he has often been referred to as a semi-legendary preceptor. According to various traditions, he is considered to have lived some time between the ninth and thirteenth centuries. Historically, the geographic location of his origins have been as highly contested as the period in which he lived, and there appears to be no empirical evidence which records his historical existence at all.

This problem of geographically locating a historical Gorakhnāth has not been overlooked by leaders of the Nāth community (sampradāy). 
Recent printed publications from the Gorakhnāth Mandir in Gorakhpur, Uttar Pradesh, India, attempt to explain the yogi's ambiguous historic background by claiming that Gorakhnāth was present in all four of the Hindu eras or yugs, living in four different places. "satyayug mem

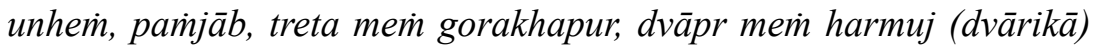
aur kaliyug mem kațhiyavar ke gorakhmaịdhī sthān me [sic] yogadeh mem abhivyakt kahā gayā haim " [It has been said of him that he existed in the body of a yogi in Panjab in the first era, the golden age, in Gorakhpur in the second era, the silver age, in Harmuj (Dwarka) in the third era, and in the fourth, dark age [he lives] in the cave of Gorakhmandhi at Kathiawar (Gujarat) (Srivastar, iv).

Due to the obvious uncertainty surrounding this ascetic's historicity, some scholars such as Mohan Singh have speculated that the name Gorakhnāth was given as a general designative appellation. Singh proposes that Gorakhnāth may be a title that was applied to holy men who have achieved a certain amount of yogic aptitude (Gorakhnäth, 2). Regardless of the lack of documentation surrounding the life of Guru Gorakhnāth, Gorakh has been attributed the authorship of a variety of philosophical, literary and instructional texts, which makes him in a very real sense an Author.

The oeuvre attributed to Gorakhnāth is primarily composed of philosophical treatises and yogic manuals. Gorakhnāth is often considered to be the celebrated author of such Sanskrit texts as Siddha Siddhānta Paddhati, Gorakașaśataka, and the Vivekamārtaṇda (Briggs, Gorakhnāth, 255; Mallinson, "Nāth Sampradāya", 413). Many of these texts emphasize the Indian philosophy of daitādait lilakșan, or "natural difference and non-difference" (Pahlajrai, "Vedanta", 9). According to Akshaya Kumar Banerjea, this is a philosophy that can only be obtained by the most enlightened yogis and is based on non-bias towards any intellectual or philosophical view (Philosophy of Gorakhnath, 55).

Besides the philosophical treatises that Gorakhnāth is accredited with, he has also been considered to be the founder of Haṭa Yoga. However in a lecture at The Oxford Centre for Hindu Studies, James Mallinson not only challenged Gorakhnāth's historical authorship of extant Sanskrit yogic texts, but denies claims that the Nāth sampradāy was mentioned at all in many of the texts attributed to Gorakhnāth ("Siddhas, 
Munis and Yogins but no Naths"). The issue of historical authorship is made even more problematic considering that the selection of texts attributed to Gorakhnāth are not solely written in the old Indo-Aryan language of Sanskrit, but also in early new Indo-Aryan languages as well. This places the language of the written works to have existed hundreds of years after even the latest dates of Gorakhnāth's purported life.

In addition to Sanskrit texts, Gorakhnāth is also credited with the authorship of literature composed in a medieval new Indo-Aryan dialect, named sant bhāṣā or sādhukharīi. Sant bhāșā, a mixed medieval dialect of Hindi, was often employed as the language of record by itinerant yogis and sants in northern India (Schmidt, "Urdu", 288). While sant bhāṣa is most often associated with the poetry of the nirgun bhaktas such as Guru Nānak and Kabīr, identifying its linguistic taxonomy is incredibly difficult (Shapiro, "Observations", 185). Due to the nomadic lifestyle of the holy men who communicated in this language, multiple linguistic differences exist between the various texts identified as being composed in sant bhāṣā.

The most well known compilation of verses attributed to the leader of the Nāth sampradāy and written in sant bhasșa is the Gorakhbānī, the sayings of Gorakhnāth. The history of the Gorakhbāni appears to parallel the history of its author, in the manner that information concerning both is largely unknown. The text is generally attributed to a late medieval context, yet the date of the composition of it is unrecorded (Barthwal, Gorakh-bāni, 12-14). However, linguistic analysis of this text indicates that it is unlikely that these verses were composed before the seventeenth century, historically situating the poetry centuries after Gorakhnāth was thought to have lived (Callewaert and Op de Beeck, Nirguna Bhakti Sagara, 37).

\section{The Bāñ̄}

The Gorakhbān̄i is divided into two parts: the śabadī or sayings of Gorakhnāth and the padas which are the poetic verses. While these sections are distinct from one another, themes reoccur in both parts. Although these themes are not particularly uncommon to other medi- 
eval South Asian literary traditions, they are crucial to understanding Gorakhnāth's role as "Author" in the Gorakhbānī. Both sections of the text emphasize the centrality of śabada (or the sacred word of the guru), the vital importance of the guru's guidance, and the ultimate goal of immortality. The abundance of passages in the text dedicated to these themes attests to their importance within the tradition.

The Gorakhbānī places an immense emphasis on śabada. While the importance of śabada in Indian religion can be located as far back as the Vedas, it is given such preeminence in the teachings of the Nāth sampradāy that some have defined the philosophy of the community as Shabadism (Vaudeville, Kabir, 139). In the Gorakhbānī, śabada is considered to be the divine word which emanates from the guru, but is not of the guru. It is considered to be the beginning and the end of everything, and the supreme revelation that exists in and of itself. The complexity and completeness of śabada in the Gorakhbāñ is illustrated in the following $s \bar{a} k h \bar{\imath}$ or verse:

sabadahim tālā sabadahim kūcì sabadhim sabada jagāyā sabadahim sabada sūm paracā hūā, sabadahim sabada samāyā.

[Sabada alone [is] the lock, sabada alone [is] the key, Only sabada awakens sabada. Only Sabada [is] acquainted with sabada, sabada alone pervades sabada] (Barthwal, Gorakh-bani, 28).

If śabada is seen to be central to the Nāth sampradāy and the message of the Gorakhbānī, then essential to receiving and understanding this revelation is the guru. This point is consistently highlighted in the text. Like many other texts devoted to tantric yoga, much of the vocabulary used in the Gorakhbān̄i is esoteric. This use of language requires that a guru explain the meaning of the text to his disciple, limiting the manner in which the text can be misunderstood. Perhaps the most distinctive characteristic of the Gorakhbāñ is its intentionally obscure rhetoric and paradoxical speech. This rhetoric may also be the most conspicuous determinant for the guru's indispensability.

Sandhābhāṣā or sandhyābhāṣā, a liminal language, and ulațavāmsī, paradoxical language, literally riddle the verses of the Gorakhbānī, 
encouraging the audiences of the text to interpret its verses in a multiplicity of ways. While both of these methods are ultimately different literary techniques, the goal and outcome of both is the same. The text is rendered "secretive" to everyone but an elite group of spiritual adepts.

The literary technique of sandhābhasṣa or sandhyābhāṣa , as its two names imply, eludes simple glosses. While bhạsā is certainly translated as speech, language or dialect, the first part of these karmadhärya compounds, sandh $\bar{a}$ and sandhy $\bar{a}$, is more complex. Sandha $\bar{a}$ is usually translated in English as "union, agreement, union or intention" and the compounded word as a whole is often translated as "intentional language" (Williams, Sanskrit-English Dictionary, 1144; Gold, The Lord as Guru, 124). While most modern scholars believe that sandhābhāṣa is the accurate term applied to this literary technique, other scholars have considered the rightful designation for these expressions to be sandyābhāss $\bar{a}$ (Bharati, "Intentional Language", 261).

Sandhyābhāṣa is often construed to mean "twilight language," as sandhya is translated as twilight or juncture. While this had been the Sanskritists' appellation of choice previous to the mid-twentieth century, in 1954 Mircea Eliade argued that there was no clear reference to the idea of sandhyābhass $\bar{a}$ in the texts. Eliade claimed that the term sandhyābhass $\bar{a}$ was a result of scribal error. He posited that scribes who had employed this term were not acquainted with the significance of sandh $\bar{a}$ and therefore altered the designation to correspond with something that they were familiar with: sandhy $\bar{a}$ (Yoga, 250).

While these dual appellations may initially appear problematic ("intentional language" implies a markedly different significance than does "twilight language"), it is possible that this is exactly the point. Regardless of the title given to this technique, what does remain clear is that this rhetoric is employed to be ambiguous. This technique employs double entendres to obscure a singular definite meaning for the poetry. The following verse displays the use of liminal language in the text:

basatī na sunyam sunyai் na basatī àgama āgocara aisā gagana-siṣara mahim bālaka bolai tākā nāìvv gharuge kaisā. 
[Inhabited is not void, void is not inhabited. Like this [it is] inaccessible and mysterious. In the mists of the heavens a young boy speaks, how will they hold onto his boat?] (Barthwal, Gorakh-bani, 21).

In addition to the manner in which I have translated the verse above, it can also be interpreted as, A) "Inhabited is not empty, empty is not inhabited. In this manner the tantric text is mysterious. At the top of the heavens the young boy speaks, how will they maintain his name?" or B) "Inhabited is not empty, empty is not inhabited. In this manner the Veda is mysterious. On the roof of the sky the young boy speaks, What kind of name will you possess?" Finally, the verse can also be understood as C) "Inhabited is not empty, empty is not inhabited. In this way the future is mysterious. In the rains of the heavens a young boy speaks, what type of boat will they possess?" Without a doubt, one can see why a guru's guidance is necessary for parsing this verse, the only thing that appears to remain consistent is mystery. The ambiguity in these sākis necessitates that a guru, or an author, lead one along the right path of meaning.

If the intent of sandayabhāșa or liminal language is ambiguity then ulatavāmsi is the rhetoric of paradox. This is not to say that liminal language does not occur in ulațavāmsī verses, however ulațavāmsī particularly thrives on turning conventional notions topsy-turvy and forcing the readers into re-considering the world as they know it. This paradoxical rhetoric conveys the tension between conventional truth and ultimate truth and attempts to coax the reader into figuring out the relationship that exists between them (Wright, "The Significance of Paradoxical Language", 325-338). The ultimate value of ulatavāmsī is considered to be the paradox itself. Its form and negation is considered to be the indispensable training tool used on yogic disciples (Eliade, Yoga, 250). An example of verse which employs this technique of ulatavāmsī is the following sāk $\overline{\text { : }}$ :

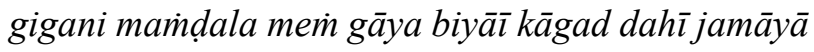

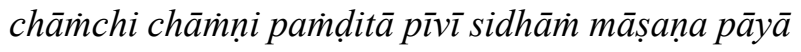


[In the orbit of heaven, a cow was born, ${ }^{1}$ Yoghurt coagulated on the paper. The pandits drank the churned buttermilk [and] the siddhas obtained the butter] (Barthwall, Gorakh-bani, 86).

There seems to be no end to the ways in which misunderstandings might occur in reading these verses of the Gorakhbāni . It is difficult to decide which tools to utilize in even beginning to deconstruct the meaning of this verse. With cows being born in heaven and coagulated yogurt being drunk and eaten by siddhas and pandits, to the uninitiated, this verse makes about as much sense as a nursery rhyme. It is confusing and humorous and appears to be non-sensical. Yet, we are told that with the help of the guru, these verses will convey messages of the utmost import. Comprehension of their meaning is the gateway to immortality.

Immortality is considered to be the ultimate goal of the Nāth sampradāy. Through meditation, asceticism, purification, and guidance the disciple gains control over his body, the microcosm of the world. However, immortality is only achieved when the yogi understands the paradoxical teachings instructed to him by his guru and this comprehension can only be accomplished through the transcendence of duality (Barthwall, Gorakh-bani, 26). It is only when the disciple is able to understand the paradoxical language and the liminal literary techniques employed in the Gorakhbānī, that the adept realizes that there was never a need for a guru in the first place. He realizes that there is no differentiation between himself and the guru.

I suggest that if we are to understand authorship through the rhetorical rubrics presented in the Gorakhbāñ we must first understand the guru and the author to be the same. If we understand the author of the Gorakhbānn to also be the ultimate guru of the Nāth sampradāy, Guru Gorakhnāth, then we are able to understand that the author is both alive and dead. He is both necessary and irrelevant to the disciple's / audience's understanding. While a vision like this may be difficult to comprehend, daitädait lilakșaṇ (or non-dual-duality between seeming-

${ }^{1}$ This translation for bayiāi is Gordan Djurdjevic's (Masters of Magical Powers, 242). 
ly opposite states) is the ultimate goal of the text. If Gorakhnāth himself states that one must die in order to become immortal, "jīvatā kai tali mūvā bichāyaba yū ụ bolyā goraș bañ̄ " [The corpse ${ }^{2}$ should be spread out [as] the base of life, thus Gorakh's uttered [his] teachings] (Barthwal, Gorakh-bani, 85), then this philosophy must also be able to be applied to ideas concerning authorship in the Gorakhbāni. The corpse of the author's authority is the base of his immortality.

If ultimately there is no inherent necessity for the guru's gloss of the Gorakhbānī, then the author's authority over the text is also expendable. The disciple/ reader/ audience is the ultimate authority over the text: the author of its meaning. Yet, the reader, the disciple, the audience could never realize their own authorial power over the text if it were not for the guidance of the guru/author. Gorakhnāth is singularly responsible for the divine word contained in the text, singularly responsible for limiting the acceptable interpretations of the text and singularly responsible for guiding spiritual neophytes along the path to immortality. $\mathrm{He}$ is the spiritual guru, the philosophical authority of the community, and the sole creator of the message of the Gorakhbāni

The paradoxical and ambiguous literary techniques and language, which are necessary for the training of the yogic disciple, highlight the problems surrounding a true understanding of the author in the Gorakhbanni. It is nearly impossible for the uninitiated to comprehend the true meaning of this paradoxical figure. The author, Gorakhnāth, is both immortal and without being. He never was and will never cease to be.

Barthes states "the birth of the reader must be at the cost of the Author," (Image, Music, Text, 148) however he was not dealing with the writings and words of Gorakhnāth. The paradoxical authorship of the Gorakhbānin, the immortality of the author and his nonexistence, is not problematic at all. It is simply another training tool employed to locate ultimate truth through the transcendence of duality. In order to understand the Gorakhbāni we need to understand that both Barthes and Fou-

\footnotetext{
${ }^{2}$ An exact English gloss for the word $m \bar{u} \square 999 v \bar{a}$ continues to be questionable, however Pitambar Datt Barthwal glosses the word in modern standard Hindi as mघ99tak, which translates to mean corpse in English.
} 
cault are both equally correct in their assertions about the Author: sole authorial power rests in neither the ideas of the author nor the reader. Authorial intent belongs to both... and to neither.

\section{REFERENCIAS}

Barthes, Roland, Image, Music, Text, trad. Stephen Heath, New York, Hill and Wang, 1977.

Bharati, A. "Intentional Language in the Tantras", Journal of American Oriental Studies, 81, 3. 1961, 261-270.

BrigGS, George Weston, Gorakhnāth and the Kānphata Yogis, Delhi, Motilal Banarsidass, 1973.

Callewaert, Winand M., and Bart Op De Beeck, Nirguna Bhakti Sāgara= Devotional Hindī Literature: a Critical Edition of the Pañc-Vān̄i or Five Works of Dādū, Kābir, Nāmdev, Raidās, Hardās with the Hindī Songs of Gorakhnāth and Sundardās, and a Complete Word-Index, New Delhi, Manohar Publications, 1991.

DJURDJEvic, Gordan, Masters of Magical Powers the Nath Siddhas in the Light of Esoteric Notions, Ottawa, Library and Archives Canada, 2006 (Bibliothèque et Archives Canada).

Eliade, Mircea, Yoga: Immortality and Freedom, Princeton, Princeton University Press, 1969.

Foucault, Michel, The Foucault Reader [1984], trad. Paul Rabinow, New York, Vintage Books, 2010.

Goraknn̄̄Th, Gōrakh-bān̄ī, trad. Pitambar Datt Barthwal, Prayag, Hindi Sahitya Sammelan, 1946.

Gold, Daniel, The Lord as Guru: Hindi Sants in North Indian Tradition, New York, Oxford University Press, 1987.

GoRAKHCARIT, Ramlal Srivastav (ed.), Gorakhpur, Gorkhnāth Mandir, 1986.

Hawley, John Stratton, "Author and Authority in the Bhakti Poetry of North India", The Journal of Asian Studies, 47, 2, 1984, 269-290.

Mallinson, James, "Siddhas, Munis, and Yogins but no Naths: The Early History of Hathayoga", Wahlstrom Lecture, Oxford, Britain, The Oxford Centre for Hindu Studies, May 19, 2009.

Mallinson, James, "Nāth Sampradāy", en Brill Encyclopedia of Hinduism, volume 3, New York, New York University Press, 2011.

Monier-Williams, Monier, Sanskrit-English Dictionary [1899], New Delhi, Munshiram Manoharlal Publishers, 2004.

Novetzke, Christian Lee, "Divining an Author: The Idea of Authorship in an Indian Religious Tradition", History of Religions, 42, 3, 2003, 213-242. 
Pollock, Sheldon, "New Intellectuals In Seventeenth-century India", The Indian Economic and Social History Review, 38, 1, 2001, 3-31.

Rose, Mark, Authors and Owners: the Invention of Copyright, Cambridge, Massachusetts, Harvard University Press, 1993.

SchмidT, Ruth Laila. "Urdu", en The Indo-Aruan Languages. George Cardona and Dhanesh Jain (ed.), London, Routledge, 2003, 386-350.

SHAPIRO, Michael C, "Observations on the Core Language of the Adigranth", Berliner Indologische Studien, 18: 3, 1987, 1-93.

Singh, Mohan, Francis Younghusband and Betty Heimann, Gorakhnath and Mediaeval Hindu Mysticism: Including Text and Translation of Machhhendra-Gorakh Goshti Padas and Shlokas of Gorakh: Shlokas of Charpatnath, Lahore, Oriental College, 1937.

Vaudeville, Charlotte, Kabir, Oxford, Clarendon Press, 1974.

Wright, Dale S, "The Significance of Paradoxical Language in Hua-yen Buddhism”, Philosophy East and West, 32, 3, 1982, 325-338. 